\title{
VISITING AND RE-VISITING TOURIST DESTINATION DUBROVNIK
}

\author{
Marija Dragicevic Curkovic
}

https://doi.org//10.20867/tosee.06.13

\begin{abstract}
Purpose - According to the researchers there are different factors influence visiting and revisiting tourist destination. The paper present the results of the research referring to the customers satisfaction with the elements of tourist offer, as well as the factors important for the first visit and re-visit to the tourist destination Dubrovnik. The aim of the paper is to explore the customers' satisfaction with components of the tourist destination product and importance of chosen factors during the first visit and re-visit to the tourist destination Dubrovnik.

Methodology - For the purpose of this paper the primary research has been carried out in Dubrovnik in 2018. including the sample of 420 tourists. The $25 \%$ of tourists have been re-visitors. The questionarre has had three different groups of questions. The first group of questions refered to the sociodemographic characteristics of respondents, the second to the source of information, third group of questions to the customers' satisfaction with elements of tourist offer and the fourth group of questions referred to the factors important for visiting and re-visiting tourist destination Dubrovnik.

Findings - According to the data which has been collected in Dubrovnik there is no significant difference in customers' satisfaction level with accomodation facilities during the first visit and revisit. The similar situation is in the area of food and restaurants services, entertainment facilities and excursions, but there is a decreasing satisfaction with transport and shopping. It is also visible that the price of the tourist product is not the important element for first itme visitors and revisitors. Reducing the risk of an unsatisfactory experience is important for the first time visitors, and also for re-visitors to tourist destination Dubrovnik. To experience some aspects which were omitted on a previous visit is especially important for re-visitors. The return visitors have pointed out the importance of achieving some experience in a different/ new way and they have stated it as very high priority element.

Contribution - The paper defines new elements important for re-visiting tourist destination Dubrovnik. The results of the primary reseach and provided recommendations based on the results of the research could be used in planning and creating tourist destination offer.
\end{abstract}

Keywords: first visit, revisit, factors, tourist destination, Dubrovnik.

\section{INTRODUCTION}

The repeat visitation is very important in the tourism industry (Ayuningtiyas, Nirman and Hamid 2014). Research shows that some visitors tend to revisit the destination when they feel satisfied with the particular attributes during their first visit (Kozak 2001). Although satisfaction with the particular destination appears to be necessary condition for explaining repeat visitations, it is not sufficient to explain this phenomenon since many respondents reported satisfactory experiences did not return to the same destinations (Pereda 2002). 
ToSEE - Tourism in Southern and Eastern Europe, Vol. 6, pp. 187-194, 2021.

M. Dragicevic Curkovic: VISITING AND RE-VISITING TOURIST DESTINATION DUBROVNIK

Perceived service quality involves customer perceptions of service quality based on a comparison of their desires or expectations and the actual received service (Ratanavaraha et al. 2016). The current visitors may affect also other people's likelihood when they show their own perception of the visit and their intention for a second visit (Darnell \& Johnson 2001). Customer satisfaction can be assessed in terms of interest, enjoyment, surprise, wise choice and doing the right thing (Horvath and Michalkova 2012). Berezina et al. (2012) found that satisfaction, revisit intention and word of mouth all have significant impact on customer perceptions of service quality. Soleimani and Einolahzadeh have carried out the research in 2016. and 2017. included the 500 travellers. The results showed that good quality of travel agencies leads to an intention to revisit destination. Moreover, the service quality had direct impact on customer satisfaction and image and there was a direct, positive relationship between customer satisfaction and word-of -mouth (Soleimani and Einolahzadeh 2018). Pleasure and arousal are two important dimensions of customer motions. In service encounters, consumers emotions have been shown tom affect customer satisfaction, loyalty and future behavioural intentions (Mishra, Bakshi and Singh 2016). Ha and Im (2012) found out that consumer emotion in the area of pleasure and arousal together with cognitive element have influenced on customers' satisfaction. Positive WOM have been considered as a result of consumers' satisfaction with actions provided by service encounters and has been connected with positive attitudes towards service recovery.

The satisfaction according to the Hui et al (2007) model shows that the satisfaction and repeat visit are in the connection. In their model for measuring tourist satisfaction they explain the dependence of customers' repeat purchase and tourists' experience.

A comparative empirical study done by Kozak (2001) was conducted in two destinations (Spain and Turkey). The results were described as different between a mature and lessdeveloped destinations. The study used model that shows how four factors affect the intention to return: satisfaction level, number of past visits to the destination, number of past visits to the country and the factors such as politic, economic and temporal. The intention to revisit according to the findings included the same visited destination as well as others in the same country. The findings may lead to the conclusion that maturity of the destination is excluded when there is a intention to revisit some other destination in the same the country. Novelty has been explored by Patrick (2002) and according to the results of the research it is visible that novelty play a role in tourists' decision towards destination. Bigne et al. (2009) find out that novelty is more important than satisfaction for the return intention. Assaker et al. (2010) also point out the importance of novelty and they connect novelty with the customers' satisfaction, what is both important for revisiting intention.

The goal of the paper was to explore the tourist perceptions towards the elements of tourist destination product and to define the other elements (besides the quality), important for the first visit and revisit to tourist destination Dubrovnik. 
ToSEE - Tourism in Southern and Eastern Europe, Vol. 6, pp. 187-194, 2021.

M. Dragicevic Curkovic: VISITING AND RE-VISITING TOURIST DESTINATION DUBROVNIK

\section{THE RESULTS OF THE RESEARCH CARRIED OUT IN TOURIST DESTINATION DUBROVNIK}

\section{Research methodology}

For the purpose of this paper the primary research has been carried out in Dubrovnik including the sample of 420 tourists. The questionnaire has had four different groups of questions. The first group of questions refered to the sociodemographic characteristics of respondents, the second to the source of information, third group of questions to the customers' satisfaction with elements of tourist offer and the fourth group of questions referred to the factors important for visiting and re-visiting tourist destination Dubrovnik. The aim of the research was to find out the satisfaction level with elements of tourist supply and define the factors influenced on visiting/ revisiting tourist destination Dubrovnik. The share of $25 \%$ of tourists have been re-visitors. The descriptive statistic has been used for analysing the data.

\section{The results of the research and discussion}

According to the data obtained from the primary research the share of $45 \%$ belonged to the woman, and $55 \%$ to the man. The share of $25 \%$ of tourists were from USA, $38 \%$ from Great Britain, $15 \%$ from Korea, $17 \%$ from Japan and 5\% of tourists have been from different another countries. In the research the tourist of different ages have been included, so the $38 \%$ of respondents were up to the $35,46 \%$ between 36 and 50 , and $16 \%$ older than 51 . Most of the respondents have finished secondary school, $56 \%$ of them, $42 \%$ of them have had university diploma and $2 \%$ of respondents have had doctoral or master degree. The share of $25 \%$ of the tourists were in category until 1000 euro referring to the criterion of income, $30 \%$ of the respondents have had more than 1500 euro, and $45 \%$ have had between 1000 and 1500 euro. The share of $25 \%$ have been re-visitors and the rest have been first time visitors.

According to the results of the research it is visible that the share of $72 \%$ of respondents informed themselves through Internet as the source of information when they plan their first visit and $25 \%$ of them were very satisfied, $35 \%$ were satisfied, $35 \%$ were partially satisfied, $3 \%$ were unsatisfied and $2 \%$ were completely unsatisfied with this source of information. The situation is just a little bit different with re-visitors, who were mostly very satisfied and satisfied with Internet as the source of information. The first time visitors also used the advice of travel agency (65\% of them) and the share of $35 \%$ of respondents were very satisfied, $30 \%$ were satisfied, $25 \%$ were partially satisfied, $5 \%$ were unsatisfied and $5 \%$ were completely unsatisfied with travel agency as the source of information. The revisitors used less travel agency advice and they shown higher level of satisfaction with information provided by travel agencies, so they were mostly satisfied and very satisfied, $85 \%$ of them and the rest of $15 \%$ were partially satisfied with the travel agency as service provider. Tourist also contacted their friend and relatives and they shown the high level of satisfaction with the information provided from their friends and relatives, what was the especially the case of the first time visitors. The share of $95 \%$ of respondents find out that they were very satisfied and satisfied with this source of information. The tourists have been asked to assess the factors which have influenced on the their first visit. 
ToSEE - Tourism in Southern and Eastern Europe, Vol. 6, pp. 187-194, 2021.

M. Dragicevic Curkovic: VISITING AND RE-VISITING TOURIST DESTINATION DUBROVNIK

Table 1: The first time visitors factors' assessment

\begin{tabular}{|c|c|c|c|c|c|}
\hline \multirow[b]{2}{*}{ Factors } & \multicolumn{5}{|c|}{ Importance } \\
\hline & $\begin{array}{r}\text { Very } \\
\text { Important } \\
(\%) \\
\end{array}$ & $\begin{array}{r}\text { Important } \\
(\%) \\
\end{array}$ & $\begin{array}{r}\text { Partially } \\
\text { Important } \\
(\%) \\
\end{array}$ & $\begin{array}{r}\text { Has less } \\
\text { Importance } \\
(\%) \\
\end{array}$ & $\begin{array}{r}\text { Completely } \\
\text { Unimportant } \\
(\%) \\
\end{array}$ \\
\hline $\begin{array}{l}\text { Be in a familiar and } \\
\text { comfortable place }\end{array}$ & 42 & 40 & 11 & 3,5 & 3,5 \\
\hline $\begin{array}{l}\text { To experience some aspects } \\
\text { which were omitted on a } \\
\text { previous occasion }\end{array}$ & - & 62 & 30 & 5 & 3 \\
\hline $\begin{array}{l}\text { Emotionally attached to the } \\
\text { destination }\end{array}$ & 8 & 34 & 34 & 10 & 14 \\
\hline No alternatives & 10 & 25 & 25 & 5 & 35 \\
\hline $\begin{array}{l}\text { To expose others to the } \\
\text { experiences which previously } \\
\text { have been satisfying }\end{array}$ & 17 & 35 & 23 & 12 & 13 \\
\hline $\begin{array}{l}\text { To reduce the risk of an } \\
\text { unsatisfactory experience }\end{array}$ & 20 & 25 & 25 & 15 & 15 \\
\hline $\begin{array}{l}\text { Because of partners' } \\
\text { influence }\end{array}$ & 14 & 30 & 31 & 18 & 7 \\
\hline $\begin{array}{l}\text { Because of proximity to other } \\
\text { destinations }\end{array}$ & 16 & 40 & 26 & 16 & 2 \\
\hline
\end{tabular}

Source: author

Table 2: The re- visitors assessment

\begin{tabular}{|c|c|c|c|c|c|}
\hline \multirow[b]{2}{*}{ Factors } & \multicolumn{5}{|c|}{ Importance } \\
\hline & $\begin{array}{r}\text { Very } \\
\text { Important } \\
(\%) \\
\end{array}$ & $\begin{array}{r}\text { Important } \\
(\%) \\
\end{array}$ & $\begin{array}{r}\text { Partially } \\
\text { Important } \\
(\%)\end{array}$ & $\begin{array}{r}\text { Has less } \\
\text { Importance } \\
(\%)\end{array}$ & $\begin{array}{r}\text { Completely } \\
\text { Unimportant } \\
(\%)\end{array}$ \\
\hline $\begin{array}{l}\text { Be in a familiar and } \\
\text { comfortable place }\end{array}$ & 53 & 38 & - & 4 & 5 \\
\hline $\begin{array}{l}\text { To experience some aspects } \\
\text { which were omitted on a } \\
\text { previous occasion }\end{array}$ & 27 & 54 & 17 & 2 & - \\
\hline $\begin{array}{l}\text { To experience someting in a } \\
\text { different way }\end{array}$ & 42 & 55 & 3 & - & - \\
\hline $\begin{array}{l}\text { Emotionally attached to the } \\
\text { destination }\end{array}$ & 36 & 18 & 36 & 10 & - \\
\hline No alternatives & - & 12 & 45 & 14 & 30 \\
\hline $\begin{array}{l}\text { To expose others to the } \\
\text { experiences which previously } \\
\text { have been satisfying }\end{array}$ & 37 & 46 & - & 9 & 8 \\
\hline $\begin{array}{l}\text { To reduce the risk of an } \\
\text { unsatisfactory experience }\end{array}$ & 20 & 38 & - & 21 & 21 \\
\hline $\begin{array}{l}\text { Because of partners' } \\
\text { influence }\end{array}$ & 41 & 40 & - & 19 & - \\
\hline $\begin{array}{l}\text { Because of proximity to other } \\
\text { destinations }\end{array}$ & 18 & 37 & 18 & 20 & 7 \\
\hline
\end{tabular}

Source: author

According to the results of the primary research it is visible that $82 \%$ of first time visitors considered that to be in a familiar and comfortable place was important and very important $11 \%$ of them thought it was partially important, 3,5\% considered it had low level of 
ToSEE - Tourism in Southern and Eastern Europe, Vol. 6, pp. 187-194, 2021.

M. Dragicevic Curkovic: VISITING AND RE-VISITING TOURIST DESTINATION DUBROVNIK

importance and 3,5\% of them think it was not important at all. According to the results of the primary research referred to the re- visitors it was visible that $91 \%$ of return visitors considered that be in a familiar and comfortable place was important, $4 \%$ considered it had low level of importance and 5\% of them thought it was not important at all.

To experience some aspects which were omitted on a previous occasion was important for $62 \%$, partially important for $30 \%$, had small importance for $5 \%$ and was not important at all for $3 \%$ of first time visitors. The same indicator was important for $81 \%$ of re-visitors, had small importance for $17 \%$ of them and was not important at all for $2 \%$ of them.

To be emotionally attached to the destination was important for $42 \%$ of first time visitors, partially important for $34 \%$ of them, had small importance for $10 \%$ of them and was not important at all for $14 \%$ of tourists. To be emotionally attached to the destination was important for $54 \%$ of re-visitors, partially important for $36 \%$ of them, had small importance for $10 \%$ of them.

To expose others to the experiences which previously was important for $52 \%$ of first time visitors, partially important for $23 \%$, had low level of importance for $12 \%$ of them and it was not important at all for $13 \%$ of tourists. To expose others to the experiences which previously was important for $83 \%$ of re-visitors, had low level of importance for $9 \%$ of them and it was not important at all for $8 \%$ of tourists. So, it is visible that there is no significant difference between first time visitors and re-visitors. According to the primary data it is visible that re-visitors expected that they should experience something in a different way and it was very important and important for $97 \%$ of them and for only $3 \%$ of re-visitors it was partially important.

To reduce the risk of an unsatisfactory experience was important for $45 \%$ of first time visitors, $25 \%$ of them thought it was partially important, $15 \%$ consider it had small importance and $15 \%$ think it was not important at all. To reduce the risk of an unsatisfactory experience was important for $58 \%$ of re-visitors, $21 \%$ considered it had small importance and $21 \%$ thought it was not important.

The share of $44 \%$ of tourists considered that the partners' influence was very important for their first visit, 33\% of them considered it was partially important, 18\% thought it had low level of importance and 7\% of tourist thought it was not important. The share of $44 \%$ of tourists considered that the partners' influence was very important for their first visit, 33\% of them considered it was partially important, $18 \%$ thought it had low level of importance and $7 \%$ of tourist thought it was not important. The results of the research shown that $81 \%$ of re-visitors thought that partners' influence was important and $19 \%$ consider that it was not important at all.

The results referred to the first time visitors shown that $56 \%$ of them thought that proximity to other destinations was important, for $26 \%$ it was partially important, $16 \%$ considered that it had small level of importance and $2 \%$ considered it was not important at all. The share of $55 \%$ of re-visitors found out that the proximity to other destination was important, for $18 \%$ of them it was partially important, $20 \%$ of tourists thought it had low level of importance and $7 \%$ thought that the proximity to other destinations was not important at all. 
ToSEE - Tourism in Southern and Eastern Europe, Vol. 6, pp. 187-194, 2021.

M. Dragicevic Curkovic: VISITING AND RE-VISITING TOURIST DESTINATION DUBROVNIK

The share of $35 \%$ of first time tourists thought that no alternatives solution was important, while $25 \%$ of them thought that it was partially important, $7,5 \%$ considered that it had low level of importance and 35\% considered that it was not important at all. The results of the research referred to the re-visitors shown that $12 \%$ of tourists who were re-visitors considered that no alternative solution was important, $45 \%$ thought it was partially important, $14 \%$ of them considered it had low level of importance and $30 \%$ of them thought that it was not important at all.

It was visible that the factors influenced the first visit to the tourist destination Dubrovnik were in some areas similar like the factors which have influenced the re-visit to the tourist destination Dubrovnik.

The next group of questions referred to the satisfaction with the elements of tourist destination product.

Table 3: The first time visitors assessment

\begin{tabular}{lrrrrr}
\hline & \multicolumn{3}{c}{ Satisfaction } & \\
\cline { 2 - 6 } Service & $\begin{array}{r}\text { Very } \\
\text { satisfied } \\
(\%)\end{array}$ & Satisfied & $\begin{array}{r}\text { Partially } \\
\text { Satisfied } \\
(\%)\end{array}$ & $\begin{array}{r}\text { Unsatisfied } \\
(\%)\end{array}$ & $\begin{array}{r}\text { Completely } \\
\text { unsatisfied } \\
(\%)\end{array}$ \\
\hline Accomodation & 53 & 35 & 10 & 2 & \\
Food/restaurants & 32 & 39 & 23 & 6 & \\
Entertainment & 15 & 50 & 30 & 5 & 12 \\
Transport & 35 & 33 & 22 & 10 & \\
Shopping & 9 & 18 & 38 & 23 & 4 \\
Excursions & 28 & 51 & 17 & & \\
\hline
\end{tabular}

Source: author

Table 4: The re- visitors assessment

\begin{tabular}{|c|c|c|c|c|c|}
\hline \multirow[b]{2}{*}{ Service } & \multicolumn{5}{|c|}{ Satisfaction } \\
\hline & $\begin{array}{r}\text { Very } \\
\text { satisfied } \\
(\%)\end{array}$ & $\begin{array}{r}\text { Satisfied } \\
(\%)\end{array}$ & $\begin{array}{r}\text { Partially } \\
\text { Satisfied } \\
(\%)\end{array}$ & $\begin{array}{r}\text { Unsatisfied } \\
\qquad(\%)\end{array}$ & $\begin{array}{r}\text { Completely } \\
\text { unsatisfied } \\
(\%)\end{array}$ \\
\hline Accomodation & 42 & 42 & 14 & 2 & \\
\hline Food/restaurants & 66 & 25 & 9 & - & \\
\hline Entertainment & 16 & 58 & 19 & 7 & \\
\hline Transport & 41 & 16 & 35 & 8 & \\
\hline Shopping & 23 & 22 & 30 & 25 & \\
\hline Excursions & 27 & 49 & 20 & 4 & \\
\hline
\end{tabular}

Source: author

According to the results of the research referred to the first time visitors it was visible that $88 \%$ of clients were satisfied with accommodation, $10 \%$ of them were in the category of partially satisfied and 2\% were unsatisfied. According to the results of the research $84 \%$ of clients who revisited Dubrovnik were satisfied clients, $14 \%$ of them were partially satisfied and $2 \%$ of them were unsatisfied with the accommodation facilities. It is visible that there is no significant difference between first time visitors and re-visitors. The share of $71 \%$ of clients were satisfied with food and restaurants services, $23 \%$ of them were partially satisfied and 6\% were unsatisfied in the first visit. According to the results of the research $91 \%$ of tourists who re-visited Dubrovnik were satisfied with food and restaurants services 
ToSEE - Tourism in Southern and Eastern Europe, Vol. 6, pp. 187-194, 2021.

M. Dragicevic Curkovic: VISITING AND RE-VISITING TOURIST DESTINATION DUBROVNIK

and $9 \%$ were partially satisfied. There was no tourists in the category of unsatisfied, so it could be stated that the re-visitors had higher level of satisfaction with food and restaurants services.

According to the results of the research referring to the first time visitors the share of $65 \%$ of tourists considered that they were satisfied with entertainment, $30 \%$ of them were partially satisfied and $5 \%$ of them were not satisfied with entertainment facilities. The share of $74 \%$ of re-visitors were satisfied with the entertainment facilities, $19 \%$ of them were partially satisfied and $7 \%$ were not satisfied with entertainment services. There was a growth of satisfied clients and decreasing number of partially satisfied tourists, but there was also a slight growth of unsatisfied clients. The share of $68 \%$ of tourists were satisfied with transport, $22 \%$ of them were partially satisfied and $10 \%$ of them were not satisfied with transport in Dubrovnik in the first visit. The results of the research shown that $57 \%$ of re-visitors were satisfied with transport, $35 \%$ of them were partially satisfied and $8 \%$ of them were not satisfied with transport. It is visible that there was a decreasing number of satisfied tourist who are re-visitors.

According to the results of the research the share of $27 \%$ of tourists who were first time visitors were satisfied with shopping, $38 \%$ of them were partially satisfied and $35 \%$ were not satisfied with shopping facilities. The results of the research shown that $45 \%$ of tourists who were re-visitors were satisfied shopping services, $30 \%$ of them were partially satisfied and $25 \%$ were not satisfied. According to the results of the research it was visible that revisitors shown increasing level of satisfaction with the shopping services. The $79 \%$ of first visitors were satisfied with excursions, $17 \%$ of them were in category of partially satisfied and $4 \%$ of them were in category of unsatisfied clients. According to the results of the research it is also visible that $76 \%$ of re-visitors were satisfied with excursions, $20 \%$ were in the category of partially satisfied and $4 \%$ of them were not satisfied with excursions.

\section{CONCLUSION}

The challenge for tourist destination is to find out the appropriate strategies and encourage tourists to revisit the destination. They also feel contented when the value of the service they receive matches the price they pay for the service ( $\mathrm{Lu}$ et al. 2015). According to the results of the research it was visible that the price of the tourist product was not the main element for choosing Dubrovnik. There was no significant difference between first time visitors and return visitors referring to the satisfaction with the quality of elements of tourist destination product in the area of accommodation facilities, entertainment and excursions, but there is a decreasing level of satisfaction of return visitors in the area of transport and increasing level of return visitors' satisfaction in the area of food and restaurant services. Reducing the risk of an unsatisfactory experience was important for first time visitors, and re-visitors of tourist destination Dubrovnik. To experience some aspects which were omitted on a previous occasion and to experience something in a different way were two high positioned element, especially for return visitors, so it should be taken into account in strategic planning and implementation of innovation and creation (co-creation) of new products in the future development. 
ToSEE - Tourism in Southern and Eastern Europe, Vol. 6, pp. 187-194, 2021.

M. Dragicevic Curkovic: VISITING AND RE-VISITING TOURIST DESTINATION DUBROVNIK

The limitations of the research have been connected with the number of tourists involved in the research and in time of the research. The research has been carried out in 2018, so the influence of Corona virus has not been explored.

\section{REFERENCES}

Assaker, G., Vinzi, V.A. and O'Connor, P. (2010), "Examining the effect of novelty seeking, satisfaction, and destination image on tourists' return pattern: A two factor, non-linear latent growth model", Tourism Management, Vol. 1, No. 12, pp. 890-901. https://doi.org/10.1016/j.tourman.2010.08.004

Ayuningtiyas, G.A., Nirman, U. and Hamid, D. (2014), "The influence of word of mouth (WOM)on revisit intention: The mediation role and of destination image (case study on domestic tourists visiting Mount Bromo)", Profit (Journal Administrasi Bisnis), Vol. 8, No, 1. doi. 10.1080/23311886.2018.1560651

Bigne, J.E., Sanchez, I. and Andreu, L. (2009), "The role of variety seeking in short and long run revisit intentions in holiday destinations", International journal of culture, tourism and hospitality research, Vol. 3, No. 2, pp. 103-115. https://doi.org/10.1108/17506180910962113

Darnell, A.C. and Johnson, P.S. (2001), "Repeat visits to attractions: a preliminary economic analysis", Tourism Management, Vol. 22, pp. 119-126. https://doi.org/10.1016/S0261-5177(00)00036-4

Ha, Y. and Im, H. (2012), "Role of web site design quality in satisfaction and word of mouth generation", Journal of Service Management, Vol. 23, No. 1, pp. 79-96. https://doi.org/10.1108/09564231211208989

Horvath, M.A. and Michalkova, A. (2012), "Monitoring Customer s satisfaction in Service Industry", Kvalita Inovacia Prosperita Quality Innovation Prosperity, Vol. 16, No. 1, pp. 49-54. https://doi.org/10.12776/qip.v16i1.61

Hui, K. T., Wan, D., Ho, A. (2007), "Tourists' satisfaction, Recommendation and Revisiting Singapore", Tourism Management, Vol. 28, No. 4, pp. 965-975.

Kozak, M. (2001), "Repeaters' behaviour at two distinct destinations", Annals of tourism research, Vol. 28, No. 3, pp.784-807. https://doi.org/10.1016/S0160-7383(00)00078-5

Lu C., Berchoux C., Marek, M.W. and Chen B. (2015), "Service quality and customer satisfaction: qualitative research implications for luxury hotels", International Journal of Culture, Tourism and Hospitality Research, Vol. 9, No. 2, pp. 168-182. https://doi.org/10.1108/IJCTHR-10-2014-0087

Mishra, P., Bakshi, M. and Singh, R. (2016), "Impact of consumption emotions on WOM in movie consumption: Empirical evidence from emerging markets", Australian Marketing Journal, Vol. 24, No.1, pp. 59-67. https://doi.org/10.1016/j.ausmj.2015.12.005

Pereda, M.H. (2002) "Repeat visitors of a tourist destination”, Journal of Travel Research, Vol. 36, No. 1. pp. 35-43.

Ratanavaraha, V., Jomnonkwao, S., Khampirat, B., Watthanaklang, D. and Iamtrakul, P. (2016), "The complex relationship between school policy, service quality, satisfaction and loyalty for educational tour bus services: A multilevel modelling approach", Transport policy, Vol. 45, pp. 116-126. https://doi.org/10.1016/j.tranpol.2015.09.012

Soleimani, A.G., Einolahzadeh, H. (2018), "The influence of service quality on revisit intention: The mediating role of WOM and satisfaction (Case study: Guilan travel agencies)", Leisure and Tourism, viewed 21 March 2021, http://www.cogentoa.com/article/10.1080/23311886.2018.1560651

Marija Dragicevic Curkovic, Associate Professor

University of Dubrovnik

Department of Economics and Business

Lapadska obala 7, Dubrovnik, Croatia

marija.dragicevic@unidu.hr 